HYDROGEOLOGIC DATA FROM A TEST WELL NEAR PONTE VEDRA, NORTHEAST ST. JOHNS COUNTY, FLORIDA

By David P. Brown, James A. Miller, and Eugene C. Hayes

U.S. GEOLOGICAL SURVEY

Open-File Report 86-410W

Prepared in cooperation with the

ST. JOHNS RIVER WATER MANAGEMENT DISTRICT

and

ST. JOHNS COUNTY

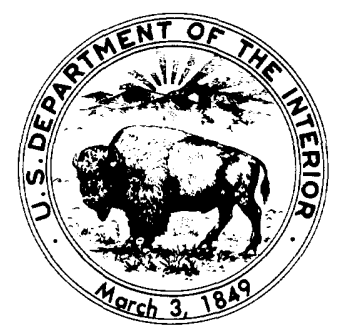

Tallahassee, Florida 
UNITED STATES DEPARTMENT OF THE INTERIOR

DONALD PAUL HODEL, Secretary

GEOLOGICAL SURVEY

Dallas L. Peck, Director

For additional information write to:

District Chief

U.S. Geological Survey

Suite 3015

227 North Bronough Street

Tallahassee, Florida 32301
Copies of this report can be purchased from:

U.S. Geological Survey Books and Open-File Reports Federal Center, B1dg. 41 Box 25425

Denver, Colorado 80225 (Telephone: (303) 236-7476) 


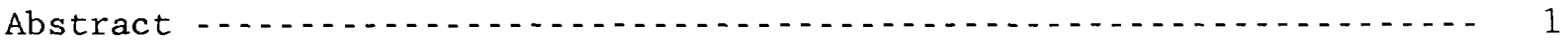

Introduction

Purpose and scope

Acknowledgments - $-\ldots \ldots-\ldots$

We11 construction -

Geologic data $-\ldots \ldots \ldots$

Hydrologic data

Water levels $\ldots \ldots \ldots \ldots 22$

Artesian flow - . $\ldots \ldots \ldots \ldots 22$

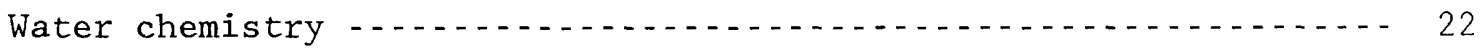

Selected references $\ldots \ldots \ldots \ldots$

\section{ILLUSTRATIONS}

Figure 1. Map showing location of test wel1 $\ldots \ldots \ldots$

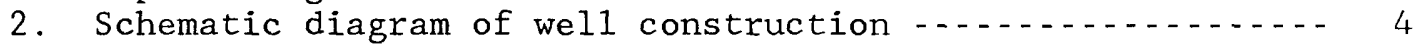

3. Diagram showing lithology at test wel1 site $\ldots . . . . . . .17$

4. Electric log; long and short normal resistivity, and spontaneous potential $\ldots \ldots 18$

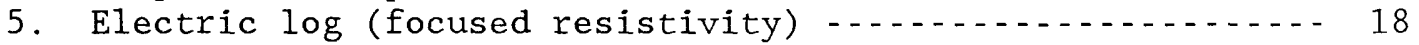

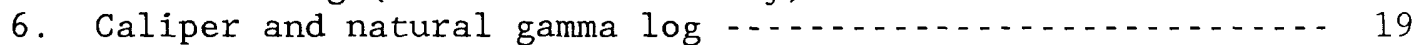

7. Neutron porosity $\log \ldots \ldots \ldots \ldots$

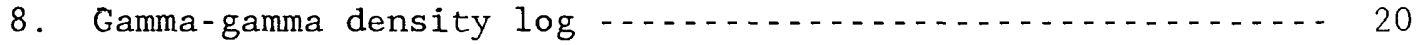

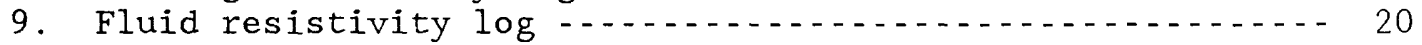

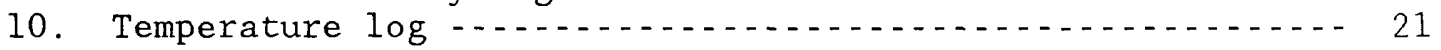

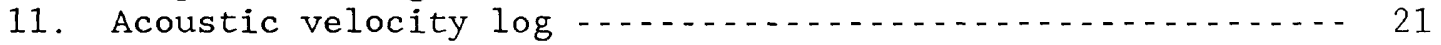

12. Water levels in drill stem and in annulus during drilling of test well $\ldots \ldots \ldots . \ldots \ldots$

13. Artesian flow of test well during drilling $\ldots \ldots . . . . . . .24$

14. Flow-meter traverse in test we11, open-hole interval 335 to 818 feet below land surface $\ldots \ldots \ldots$

15. Flow-meter traverses in test well, open-hole interval 335 to 1,381 feet below land surface $\ldots \ldots$

16. Flow-meter traverses in test well, open-hole interval

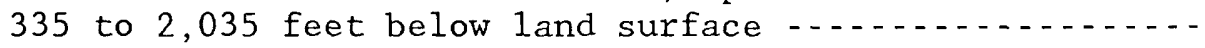

17. Specific conductance of water obtained from the drill stem and the annulus as the test well was drilled from 342 to 2,035 feet $\ldots \ldots \ldots$

18. Chloride concentrations of water obtained from the drill
stem and annulus as the test well was drilled from 342 to 2,035 feet $\ldots \ldots \ldots$

19. Temperature of water obtained from the drill stem and annulus as the test well was drilled from

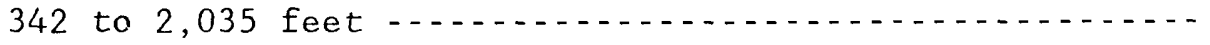

TABLE 


\title{
HYDROGEOLOGIC DATA FROM A TEST WELL NEAR PONTE VEDRA, NORTHEAST ST. JOHNS COUNTY, FLORIDA
}

\author{
By David P. Brown, James A. Miller, and Eugene C. Hayes
}

\begin{abstract}
A 2,035-foot test we11 was drilled in northeast St. Johns County, Florida, to obtain hydrogeologic and water chemistry data. Drill cuttings and water samples were collected, and water-level measurements and lithologic and geophysical logs were made. The deposits to a depth of 313 feet consist of sand, clayey sand, phosphatic sandy clay, coquina, sandy limestone, and dolomite. Below 313 feet, the deposits consist of limestone, dolomitic limestone, and dolomite, which comprise the Floridan aquifer system in the area.
\end{abstract}

Water levels measured through the drill stem as drilling progressed from 373 to 1,980 feet ranged from 24 feet above land surface at a depth of 548 feet to 33.0 feet above land surface at a depth of 1,790 feet. After the lower saline water-bearing zone was penetrated at a depth of 1,983 feet, water level decreased to 4.9 feet below land surface. Water levels measured in the annular space ranged from 23.7 feet above land surface at a depth of 548 feet to 33.1 feet at a depth of 1,790 feet. Flow of the test well ranged from about 72 gallons per minute at a depth of 338 feet to 2,340 gallons per minute at a depth of 1,703 feet.

Chloride concentrations of drill stem samples from a depth of 343 to 1,023 feet ranged from 12 to 31 milligrams per liter. Below the 1,023-foot depth, chlorides increased to as much as 270 milligrams per liter at 1,025 feet, varied between 12 and about 38 milligrams per liter from 1,093 feet to 1,973 feet, and reached a maximum of 16,210 milligrams per liter at 2,023 feet. Water temperatures of drill stem samples ranged from 23 to 27 degrees Celsius.

\section{INTRODUCTION}

\section{Purpose and Scope}

Little information is available on the hydrogeology of the saline-water zones of the Floridan aquifer system below a depth of 1,500 feet and the interconnection of these zones with the overlying freshwater zones in the northeast Florida area. Information on water levels, the location of the freshwater-saltwater interface, and on water chemistry is necessary to determine the relation between withdrawals of water from the freshwater zones and saltwater intrusion. The information will aid in assessing the availability of potable water from the Floridan aquifer system. 
The U.S. Geological Survey, in cooperation with the St. Johns River Water Management District and St. Johns County, is investigating the hydrogeology and water chemistry of the deep zones of the Floridan aquifer system. An essential part of this investigation is the drilling, testing, and instrumentation of a network of five to seven deep test wells. This report contains geologic and hydrologic data collected during construction of a test well drilled near Ponte Vedra, northeast St. Johns County. The well will be used to monitor ground-water levels and water chemistry. The information from the test well will help determine the depth and change of position of the freshwater-saltwater interface. The Ponte Vedra Test Well is the third well drilled under this program.

\section{Acknowledgments}

The authors wish to express their appreciation to the Governing Board and staff of the St. Johns River Water Management District and to the Board of County Commissioners and staff of St. Johns County for their support of this investigation. Particular acknowledgment is given to Douglas Munch, Director, Resource Evaluation Division, St. Johns River Water Management District, and to J. L. Harrington, County Administrator, and Gene Burns, Department of Public Works, St. Johns County.

\section{WELL CONSTRUCTION}

The location of the test well is shown in figure 1. Construction of the well took place from August to October 1985. As shown in figure 2, the well was drilled to a depth of 2,035 feet below land surface. It was drilled to a depth of 345 feet by the standard mud-rotary method, then a 12-inch diameter steel casing was installed from land surface to a depth of 335 feet and grouted from the bottom of the hole to the surface. The remainder of the hole, 345 to 2,035 feet, was drilled by the reverse-air rotary method. A 6 -inch diameter steel casing was installed from land surface to a depth of 1,980 feet and grouted from that depth to land surface. The interval from 1,980 to 2,035 feet was left open to the formation.

\section{GEOLOGIC DATA}

Drill cuttings were collected at intervals of about 5 to 10 feet and at changes in lithology (table 1). The deposits to a depth of 313 feet consist of sand, clayey sand, phosphatic sandy clay, coquina, sandy limestone, and dolomite (fig. 3). These materials range in age from Miocene (Hawthorn Formation) to Holocene. The deposits below 313 feet consist of fragmented and granular limestone, dolomitic limestone, and massive to finely crystalline dolomite of Paleocene to Eocene age. The formations, which comprise the Floridan aquifer system in northeast Florida according to Miller (1986), in ascending order, are the Cedar Keys Formation of Paleocene age and the Oldsmar Formation, Avon Park Formation, and Ocala Limestone of Eocene age.

Geophysical logs were made during construction of the well. Logs included in this report are electric (long and short normal resistivity, spontaneous potential and focused resistivity), caliper and natural gamma, neutron porosity, gamma-gamma density, fluid resistivity, temperature, and acoustic velocity (figs. 4-11). 


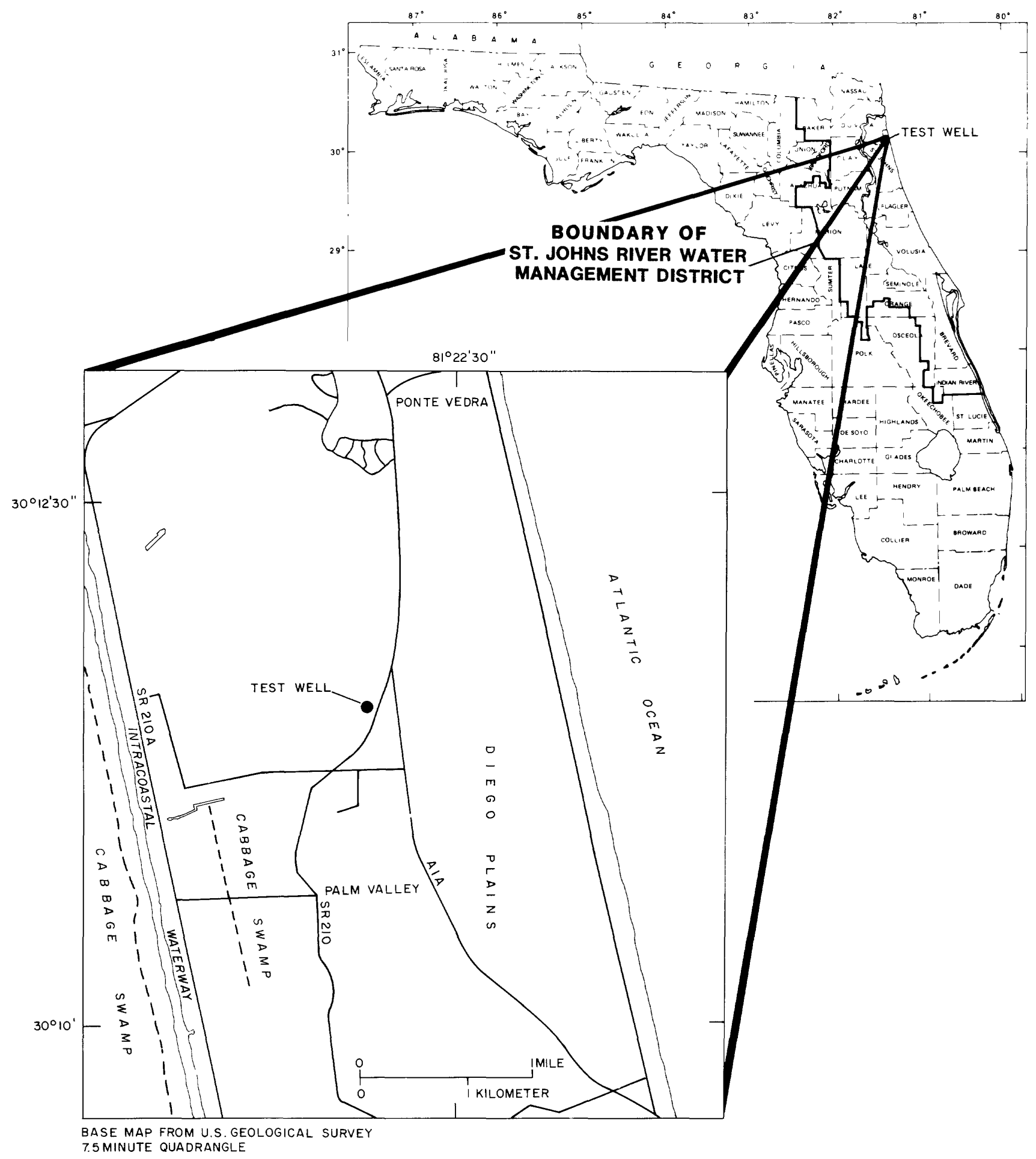

Figure 1.--Location of test well. 


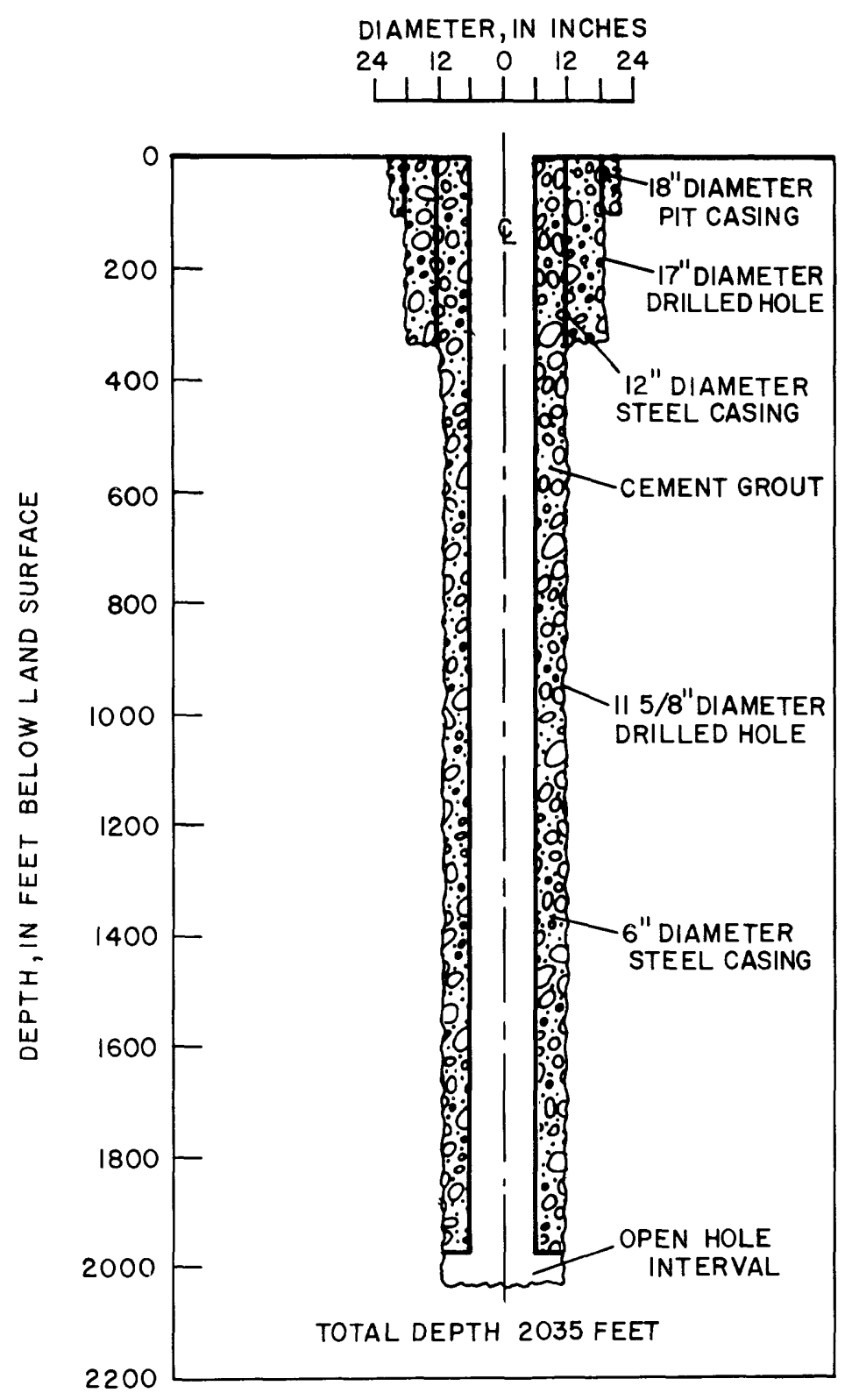

Figure 2.--Schematic diagram of well construction. 
Table 1.--Lithologic log of test well

[Depth to base, in feet below measuring point, which is 7.0 feet above land surface]

\author{
Description
}
Thick-
Depth
ness to base
(feet) (feet)

Sand and clay, medium gray with greenish cast; 80 percent

fine-grained we11-sorted quartz sand, iron-stained in part; 20 percent medium greenish-gray clay binder. Woody material prominent. Trace of fine gravel, rose quartz.

Shel1 hash, gray-white mottled. Samples consist of medium

to large broken pelecypod and gastropod fragments. Aggregates of fine-grained sand in a dark-gray clay matrix prominent. C1ay increases to 20 percent in 40 to 50-foot interval.

She11, silt, and sand, gray-white mottled; 40 percent

broken she11 fragments as above; 35 percent light-gray calcareous silt matrix; 25 percent fine- to very coarsegrained subrounded to we11-rounded quartz sand. Fine quartz gravel prominent. Trace of black coarse-grained phosphate.

As above with increase in grave1 to 20 percent, corresponding decrease in silt.

Sand, quartz, light-gray, medium- to very coarse-grained, subrounded to rounded, 10 percent 1 ight-gray calcareous silt binder. Trace of coarse-grained black phosphate. Sand coarse- to very coarse-grained in 100 to 110 -foot interval.

Sand and silt, dark greenish-gray; as 80 to 100-foot interval with increase in calcareous silt to 20 percent, corresponding decrease in sand. Lenses of olive-green clay prominent in 130 to 140 -foot interval.

Sand and silt, dark greenish gray; 60 percent medium- to very coarse-grained rounded to subrounded quartz sand; 40 percent dark greenish-gray calcareous silt matrix. Trace of coarse-grained black phosphate.

Sand, quartz, 1ight gray with greenish cast, coarse to very coarse-grained, rounded to subrounded. Light greenishgray silt binder prominent. Trace of dark-brown to black phosphate; shell fragments. Dark-green clay lenses prominent in 160 to 170 -foot interval.

Sand and clay, light olive-green; 75 percent coarse-grained well-sorted rounded to subrounded quartz sand; 25 percent dark olive-green clay binder. Dark-brown to black coarsegrained phosphate prominent. Trace of shell fragments. 
Table 1.--Lithologic $\log$ of test wel1--Continued

Description

Thick-

Depth

ness to base

(feet) (feet)

Sand and clay, phosphatic, dark olive-green with brown

cast; 40 percent fine- to medium-grained angular to subrounded quartz sand; 30 percent fine- to mediumgrained light to dark-brown phosphate; 30 percent dark olive-green silty clay matrix. Gamma-ray log shows high phosphate concentration occurs at 240 to 255 feet. Both quartz sand and phosphate are coarse.to very coarsegrained in the 260 to 270 -foot interval, where a low ganma-ray count probably indicates a sand bed.

Limestone, sandy, phosphatic, light olive-green; 65 percent

light greenish-gray well indurated dolomitic limestone matrix; 20 percent fine- to medium-grained dark-brown to black phosphate; 15 percent fine- to medium-grained subrounded to rounded quartz sand. Phosphate and sand are disseminated in the limestone.

Mixed sample; 80 percent limestone as above; 20 percent coarse-grained phosphatic sand, consisting of rounded quartz sand and black phosphate up to pea-gravel size.

Silt, phosphatic, light olive-green; 60 percent loosely consolidated dolomitic silt matrix; 25 percent mediumto very coarse-grained light- to dark-brown phosphate; 15 percent medium- to very coarse-grained rounded to subrounded quartz sand.

Dolomite, light olive-green, very fine crystalline, well indurated. Trace of fine-grained 1ight- to dark-brown phosphate, fine-grained rounded quartz sand. Phosphate very prominent in 315 to 320-foot interval.

Limestone, white, fossiliferous, pelletal, porous, semiindurated to well indurated; 40 percent white micrite matrix; 30 percent limestone pellets of medium to coarse sand size; 30 percent bryozoan fragments and large foraminifera (Lepidocyclina sp.). Trace of pelecypod fragments. Partially dolomitized in 340 to 345-foot interval.

Limestone, white, fossiliferous, very highly porous, we11 indurated. Estimated porosity, 30 percent. Mostly Lepidocyclina and Heterostegina sp., bryozoan fragments, and minor coarse pellets of limestone; 25 percent white hard micrite binder. Composed mostly of pellets in 350 to 355foot interval. Recrystallized in 355 to 360 -foot and 370 to 375-foot intervals. Very hard in 370 to 375 -foot interval. 
Table 1.--Lithologic log of test we11--Continued

Description
Thickness

(feet)
Depth to base

(feet)

Limestone, white, very fossiliferous, very porous; 85

percent bryozoan fragments and large foraminifera; 15 percent fine crystalline limestone loosely binding fossil remains. Estimated porosity 40 percent. Gyroidina crystalriverensis in 395 to 400-foot interval. Trace of very light gray coarse crystalline calcite in 385 to $390-f$ oot and 405 to 410 -foot intervals.

Limestone, white, pelletal, fossiliferous; 65 percent small

to medium pellets of micrite; 35 percent white hard micritic limestone matrix. Bryozoan fragments and large foraminifera abundant. Trace of light-gray very coarse crystalline calcite. Estimated porosity, 20 percent.

Limestone as 380 to 410-foot interval. Most fossil remains are large foraminifera (Lepidocyclina and Heterostegina sp.).

Limestone as 410 to $420-$ foot interval. Asterocyclina sp. rare in 455 to $460-$ foot interval. Sphaerogypsina globula common in 460 to 465 -foot interval.

Limestone as 420 to 440 -foot interval.

Limestone as 410 to $420-$ foot interval. Contains Asterocyclina georgiana.

Limestone, white, pelletal; 60 percent fine pellets of micrite; 40 percent soft white micrite matrix. Large foraminifera abundant. Estimated porosity, 10 percent. Limestone, white with tan cast, pelletal, cuts as thin plates; 70 percent fine pellets of micrite and miliolid foraminifera, both partly altered to tan dolomite; 30 percent tan dolomitized micrite matrix. Trace of dark green amorphous glauconite, large foraminifera. Estimated porosity, 30 percent.

Limestone as 410 to 420 -f oot interval.

Limestone as 485 to 500-foot interval with large

foraminifera prominent. Less dolomitized, more coarsely

pelletal in 515 to 530-foot interval. Soft in 530

to 535-foot interval. Very few foraminifera in 550 to 535-foot interval.

Limestone, off-white, very fine crystalline, hard, dense, 
Table 1.--Lithologic log of test well--Continued

\begin{tabular}{|c|c|c|}
\hline Description & $\begin{array}{l}\text { Thick- } \\
\text { ness } \\
\text { (feet) }\end{array}$ & $\begin{array}{l}\text { Depth } \\
\text { to base } \\
\text { (feet) }\end{array}$ \\
\hline $\begin{array}{l}\text { Dolomite, light tan, fine crystalline, hard, massive, low } \\
\text { porosity. Sacchroidal texture in } 565 \text { to } 570 \text {-foot interval. }\end{array}$ & 10 & 570 \\
\hline $\begin{array}{l}\text { Limestone, white, finely pelletal; } 50 \text { percent fine pellets } \\
\text { of white micrite; } 50 \text { percent soft to hard white micrite } \\
\text { matrix. Low porosity. Trace of bryozoan fragments, large } \\
\text { foraminifera. }\end{array}$ & 10 & 580 \\
\hline $\begin{array}{l}\text { Limestone, tan, medium crystalline, coarsely pelletal, porous. } \\
\text { Estimated porosity, } 30 \text { percent. Trace of Dictyoconus sp. }\end{array}$ & 5 & 585 \\
\hline Limestone as 570 to $580-\mathrm{f}$ oot interval but hard, dense. & 10 & 595 \\
\hline $\begin{array}{l}\text { Limestone, tan, coarsely pelletal, consists of a microcoquina } \\
\text { of Dictyoconus sp. and other large foraminifera, loosely } \\
\text { bound with tan fine to coarse crystalline limestone cement. } \\
\text { Highly porous. Estimated porosity, } 35 \text { percent. }\end{array}$ & 5 & 600 \\
\hline $\begin{array}{l}\text { Limestone as above with white micrite filling most spaces } \\
\text { between pellets. Estimated porosity, } 15 \text { percent. }\end{array}$ & 10 & 610 \\
\hline $\begin{array}{l}\text { Limestone, tan, pelletal, fossiliferous; } 40 \text { percent medium to } \\
\text { large micrite pellets; } 40 \text { percent white micrite matrix, } \\
\text { partly recrystallized to tan dolomite; } 20 \text { percent large } \\
\text { Dictyoconus, Heterostegina, and microechinoids. Low } \\
\text { porosity. Fossils sparse in } 515 \text { to } 520-\text { foot interval. }\end{array}$ & 10 & 620 \\
\hline $\begin{array}{l}\text { Limestone, off-white, coarsely pelletal, highly porous. } \\
\text { Estimated porosity, } 30 \text { percent. } 65 \text { percent Dictyoconus sp., } \\
\text { other large foraminifera, and coarse micrite pellets; } \\
35 \text { percent white micrite binder. }\end{array}$ & 15 & 635 \\
\hline $\begin{array}{l}\text { Limestone, light brown, coarsely pelletal, highly porous. } \\
\text { Estimated porosity, } 35 \text { percent. } 50 \text { percent large to } \\
\text { small foraminifera and fine to coarse limestone pellets } \\
\text { in } 50 \text { percent micrite matrix. All of rock is recrystallized } \\
\text { to brown fine to coarse crystalline dolomitic limestone. } \\
\text { Decrease in porosity to about } 20 \text { percent in } 645 \text { to } 650- \\
\text { foot interval. }\end{array}$ & 15 & 650 \\
\hline $\begin{array}{l}\text { Limestone, foraminiferal, tan, well indurated, low } \\
\text { porosity; } 75 \text { percent miliolid foraminifera; } 25 \text { percent } \\
\text { matrix of light-brown fine crystalline dolomitic limestone. } \\
\text { Cone-shaped Dictyoconus sp. prominent. Highly vuggy in } \\
660 \text { to } 665-\text { foot interval. Black disseminated organic } \\
\text { material proninent in } 665 \text { to } 670-\text { foot interval. Large } \\
\text { flat Dictyoconus sp. account for } 20 \text { percent of rock in } \\
670 \text { to } 690-\text { foot interval. }\end{array}$ & 45 & 695 \\
\hline
\end{tabular}


Table 1.--Lithologic $\log$ of test wel1--Continued

\begin{tabular}{|c|c|c|}
\hline Description & $\begin{array}{l}\text { Thick- } \\
\text { ness } \\
\text { (feet) }\end{array}$ & $\begin{array}{l}\text { Depth } \\
\text { to base } \\
\text { (feet) }\end{array}$ \\
\hline $\begin{array}{l}\text { Limestone, cream, fine pelletal; } 70 \text { percent fine pellets } \\
\text { of white micrite and miliolid foraminifera; } 30 \text { percent } \\
\text { soft cream micrite binder. Soft, with trace of black } \\
\text { organic material in } 695 \text { to } 700 \text {-foot interval. }\end{array}$ & 10 & 705 \\
\hline $\begin{array}{l}\text { Limestone, tan, foraminiferal, low porosity; } 60 \text { percent } \\
\text { miliolid foraminifera and white micrite pellets; } 40 \\
\text { percent microcrystalline tan dolomitic limestone matrix. } \\
\text { Cone-shaped Dictyoconus sp. very prominent in } 715 \text { to } 720- \\
\text { foot interval. }\end{array}$ & 15 & 720 \\
\hline $\begin{array}{l}\text { Limestone as } 695 \text { to } 705 \text {-foot interval, well indurated, } \\
\text { with micrite binder } 1 \text { ight-brown to tan. }\end{array}$ & 25 & 745 \\
\hline $\begin{array}{l}\text { Limestone, white, pelletal; } 75 \text { percent fine pellets of } \\
\text { white micrite and miliolid foraminifera; } 25 \text { percent } \\
\text { white micrite binder. Trace of cone-shaped Dictyoconus } \\
\text { sp. Porosity estimated at } 15 \text { percent. Rock becomes } \\
\text { medium to coarse pelletal in } 755 \text { to } 760-\text { foot interval. } \\
\text { Trace of apple-green glauconite in } 760 \text { to } 765-\text { foot } \\
\text { interval. Recrystallized in } 770 \text { to } 780-\text { foot interval. }\end{array}$ & 35 & 780 \\
\hline $\begin{array}{l}\text { Limestone, white, coarsely pelletal, friable, highly porous. } \\
\text { Estimated porosity, } 30 \text { percent. Consists of loosely } \\
\text { cemented coarse pellets of white micrite and large } \\
\text { foraminifera. Cement is clear medium crystalline calcite. }\end{array}$ & 10 & 790 \\
\hline $\begin{array}{l}\text { Limestone, medium gray, very fine crystalline to micro- } \\
\text { crystalline, hard, low porosity. Dark-green glauconite, } \\
\text { large foraminifera common, enclosed in hard limestone } \\
\text { matrix. }\end{array}$ & 5 & 795 \\
\hline $\begin{array}{l}\text { Limestone, white, hard, low porosity; } 50 \text { percent miliolid } \\
\text { foraminifera and fine pellets of white micrite; } 50 \text { percent } \\
\text { white to cream microcrystalline } 1 \text { imestone matrix. }\end{array}$ & 5 & 800 \\
\hline $\begin{array}{l}\text { Limestone, pelletal, white, highly porous (estimated } \\
\text { porosity } 25 \text { percent). Consists of fine white micrite } \\
\text { pellets and small foraminifera loosely cemented by } \\
\text { cream coarse crystalline calcite. }\end{array}$ & 10 & 810 \\
\hline $\begin{array}{l}\text { Limestone, dark-brown, low porosity; } 60 \text { percent fine } \\
\text { crystalline dark-brown limestone matrix; } 40 \text { percent } \\
\text { white miliolid and other small foraminifera scattered } \\
\text { in matrix. }\end{array}$ & 10 & 820 \\
\hline Limestone as 800 to 810 -foot interval but well cemented. & 30 & 850 \\
\hline
\end{tabular}


Table 1.--Lithologic $\log$ of test we11--Continued

\begin{tabular}{|c|c|c|}
\hline Description & $\begin{array}{l}\text { Thick- } \\
\text { ness } \\
\text { (feet) }\end{array}$ & $\begin{array}{l}\text { Depth } \\
\text { to base } \\
\text { (feet) }\end{array}$ \\
\hline $\begin{array}{l}\text { Limestone, white, coarsely pelletal, highly porous. } \\
\text { Estimated porosity, } 35 \text { percent. Friable, consists } \\
\text { of coarse pellets of white micrite and large foraminifera } \\
\text { loosely cemented by white micrite binder. }\end{array}$ & 10 & 860 \\
\hline $\begin{array}{l}\text { Limestone as } 820 \text { to } 850 \text {-foot interval with cone-shaped } \\
\text { Dictyoconus sp. very prominent. }\end{array}$ & 10 & 870 \\
\hline $\begin{array}{l}\text { Limestone, white, foraminiferal, coarsely pelletal, friable, } \\
\text { highly porous. Estimated porosity, } 35 \text { percent. Consists } \\
\text { mostly of cone-shaped Dictyoconus sp., with minor coarse } \\
\text { pellets of white micrite, loosely cemented by white fine } \\
\text { crystalline calcite. }\end{array}$ & 5 & 875 \\
\hline $\begin{array}{l}\text { Limestone, dark-brown, medium crystalline, low porosity, } \\
\text { with } 15 \text { percent white small to large foraminffera } \\
\text { scattered throughout. Foraminifera increase to } 40 \text { percent } \\
\text { in } 880 \text { to } 885 \text {-foot interval. }\end{array}$ & 15 & 890 \\
\hline Limestone as 860 to 870 -foot interval. & 5 & 895 \\
\hline Limestone as 870 to 875 -foot interval. & 10 & 905 \\
\hline $\begin{array}{l}\text { Limestone as } 820 \text { to } 850-\text { foot interval with } 20 \text { percent white } \\
\text { micrite matrix. Coarse micrite pellets and large } \\
\text { foraminifera prominent in } 915 \text { to } 935-\mathrm{foot} \text { interval. }\end{array}$ & 30 & 935 \\
\hline $\begin{array}{l}\text { Limestone, white, micritic, hard, with fine micrite pellets } \\
\text { and smal1 foraminifera prominent. Trace of small vugs, } \\
\text { large foraminifera. Cone-shaped Dictyoconus sp. prominent } \\
\text { in } 990 \text { to } 995-\text { foot interval. }\end{array}$ & 60 & 995 \\
\hline $\begin{array}{l}\text { Limestone, pelletal, white, highly porous. Estimated } \\
\text { porosity, } 40 \text { percent. Consists of fine pellets of white } \\
\text { micrite and small foraminifera loosely cemented by white } \\
\text { micrite binder. Porosity decreases to about } 15 \text { percent in } \\
1,000 \text { to } 1,005-f \text { oot interval because of micrite filling } \\
\text { pore spaces. }\end{array}$ & 10 & 1,005 \\
\hline $\begin{array}{l}\text { Limestone, tan, pelletal, soft, low porosity; } 60 \text { percent } \\
\text { fine white micrite pellets and small foraminifera; } 40 \\
\text { percent tan fine crystalline calcite binder. }\end{array}$ & 5 & 1,010 \\
\hline $\begin{array}{l}\text { Limestone as } 1,000 \text { to } 1,005-\text { foot interval. Add trace of } \\
\text { white algal balls. }\end{array}$ & 5 & 1,015 \\
\hline $\begin{array}{l}\text { Limestone, dark-brown, fine crystalline, hard, low } \\
\text { porosity. White mfliolid foraminifera prominent, } \\
\text { scattered through brown limestone. }\end{array}$ & 5 & 1,020 \\
\hline Limestone as 1,005 to 1,010 -foot interval with cone-shaped & 5 & 1,025 \\
\hline
\end{tabular}
Dictyoconus sp. prominent. 
Table 1.--Lithologic log of test well--Continued

\begin{tabular}{|c|c|c|}
\hline Description & $\begin{array}{l}\text { Thick- } \\
\text { ness } \\
\text { (feet) }\end{array}$ & $\begin{array}{l}\text { Depth } \\
\text { to base } \\
\text { (feet) }\end{array}$ \\
\hline $\begin{array}{l}\text { Limestone, very dark brown to dull black, interbedded, } \\
\text { low porosity. Black limestone has silty texture, brown } \\
\text { is fine crystalline. }\end{array}$ & 5 & 1,030 \\
\hline $\begin{array}{l}\text { Dolomite, medium brown, fine to medium crystalline, hard, } \\
\text { massive, low porosity, with isolated vugs common. Minor } \\
\text { black mottling in } 1,035 \text { to } 1,040 \text {-foot interval. }\end{array}$ & 10 & 1,040 \\
\hline $\begin{array}{l}\text { Limestone as } 1,005 \text { to } 1,010 \text {-foot interval. Very we11 } \\
\text { indurated. }\end{array}$ & 5 & 1,045 \\
\hline $\begin{array}{l}\text { Limestone as } 1,000 \text { to } 1,005 \text {-foot interval. Much soft } \\
\text { micrite filling pores in } 1,050 \text { to } 1,055 \text {-foot and } \\
1,070 \text { to } 1,085-\text { foot interval causes decrease in } \\
\text { porosity to about } 20 \text { percent. Porosity is estimated } \\
\text { at } 35 \text { to } 40 \text { percent over remainder of interval. }\end{array}$ & 35 & 1,080 \\
\hline $\begin{array}{l}\text { Dolomite, calcareous, very dark brown, fine to medium } \\
\text { crystalline, hard, massive, low porosity, with a few } \\
\text { isolated vugs. }\end{array}$ & 5 & 1,085 \\
\hline $\begin{array}{l}\text { Dolomite, tan, hard, massive, very fine crystalline, } \\
\text { low porosity, trace of isolated small vugs. }\end{array}$ & 5 & 1,090 \\
\hline Dolomite as 1,080 to 1,085 -foot interval but 1 ight brown. & 5 & 1,095 \\
\hline $\begin{array}{l}\text { Dolomite, tan, coarse crystalline, sacchroidal, massive, } \\
\text { hard, low porosity, with trace of isolated vugs. }\end{array}$ & 20 & 1,115 \\
\hline $\begin{array}{l}\text { Limestone, white, micritic, iow porosity, with trace of } \\
\text { large foraminifera. }\end{array}$ & 5 & 1,120 \\
\hline $\begin{array}{l}\text { Limestone as } 1,045 \text { to } 1,050 \text {-foot interval. Soft in } 1,125 \\
\text { to } 1,130 \text {-foot interval. }\end{array}$ & 15 & 1,135 \\
\hline $\begin{array}{l}\text { Limestone, light brown, medium to coarse crystalline, hard, } \\
\text { low porosity, dolomitic, with white fine nicrite pellets } \\
\text { and miliolid foraminifera prominent. Trace of dark-green } \\
\text { glauconite. Vuggy in } 1,140 \text { to } 1,145 \text { - and } 1,155 \text { to } \\
1,160 \text {-f oot intervals. }\end{array}$ & 30 & 1,165 \\
\hline $\begin{array}{l}\text { Limestone, white with numerous black specks (algal remains), } \\
\text { micritic, hard, low porosity. Largely recrystallized to } \\
\text { clear fine crystalline calcite in } 1,175 \text { to } 1,180 \text {-foot } \\
\text { interval. }\end{array}$ & 15 & 1,180 \\
\hline $\begin{array}{l}\text { Limestone, light-gray, coarse crystalline (recrystallized), } \\
\text { low porosity, with a few scattered vugs. }\end{array}$ & 5 & 1,185 \\
\hline No Sample & 5 & 1,190 \\
\hline Limestone as 1,180 to 1,185 -foot interval. & 5 & 1,195 \\
\hline Limestone as 1,175 to 1,180 -foot interval. & 5 & 1,200 \\
\hline Limestone as 1,165 to 1,175 -foot interval. & 10 & 1,210 \\
\hline
\end{tabular}


Table 1.--Lithologic log of test we11--Continued

\begin{tabular}{|c|c|c|}
\hline Description & $\begin{array}{l}\text { Thick- } \\
\text { ness } \\
\text { (feet) }\end{array}$ & $\begin{array}{l}\text { Depth } \\
\text { to base } \\
\text { (feet) }\end{array}$ \\
\hline $\begin{array}{l}\text { Limestone, white, micritic, low porosity, massive. Trace } \\
\text { of fossil casts and molds. }\end{array}$ & 5 & 1,215 \\
\hline No Sample & 5 & 1,220 \\
\hline $\begin{array}{l}\text { Limestone as } 1,210 \text { to } 1,215 \text {-foot interval. Trace of } \\
\text { apple-green glauconite in } 1,225 \text { to } 1,230 \text {-foot interval. }\end{array}$ & 10 & 1,230 \\
\hline $\begin{array}{l}\text { Limestone, white, fossiliferous, hard, low porosity; } 60 \\
\text { percent casts and molds of fossils, chiefly bryozoa with } \\
\text { some pelecypods; } 40 \text { percent white micrite matrix. Trace } \\
\text { of scattered very fine-grained black glauconite. }\end{array}$ & 10 & 1,240 \\
\hline $\begin{array}{l}\text { Limestone, white, micritic, low porosity; small foraminifera } \\
\text { and dark-green glauconite prominent. Pyrite common in } \\
1,250 \text { to } 1,255 \text {-foot interval. Largely recrystallized to } \\
\text { coarse crystalline light gray calcite in } 1,275 \text { to } 1,280- \\
\text { foot interval. }\end{array}$ & 40 & 1,280 \\
\hline $\begin{array}{l}\text { Dolomite, dark-gray, very fine to fine crystalline, hard, } \\
\text { massive, low porosity, with light-green disseminated } \\
\text { glauconite prominent. Trace of isolated vugs. }\end{array}$ & 5 & 1,285 \\
\hline $\begin{array}{l}\text { Limestone, dolomitized, white and dark-gray mottled; } 55 \\
\text { percent white micritic limestone, low porosity; } 45 \text { percent } \\
\text { dark-gray coarse crystalline sacchroidal dolomite, } \\
\text { replacing micrite as blebs and stringers. Micrite is } \\
\text { fossiliferous (mostly small foraminifera) in } 1,295 \text { to } \\
1,300-\text { foot interval. }\end{array}$ & 15 & 1,300 \\
\hline $\begin{array}{l}\text { Limestone, light-gray, pelletal; } 75 \text { percent coarse pellets } \\
\text { of white micrite and broken bryozoan fragments; } 25 \text { percent } \\
\text { matrix of white micrite with abundant dark-green glauconite. } \\
\text { Trace of vuggy porosity. Dark-gray recrystallized } \\
\text { glauconitic 1imestone prominent in } 1,310 \text { to } 1,315-\text { and } \\
1,330 \text { to } 1,335-f o o t \text { intervals. Very wel1 indurated, } \\
\text { very low porosity, little glauconite in } 1,320 \text { to } 1,330- \\
\text { foot interval. }\end{array}$ & 40 & 1,340 \\
\hline $\begin{array}{l}\text { Limestone, medium gray, pelletal, low porosity; } 55 \text { percent } \\
\text { fine to medium pellets of white micrite and bryozoan } \\
\text { fragments; } 45 \text { percent dark-gray recrystallized limestone } \\
\text { matrix. Very fine-grained dark-green glauconite prominent } \\
\text { in matrix. Stringers of dark-gray recrystallized limestone } \\
\text { prominent in } 1,345 \text { to } 1,350-\text { foot interval. }\end{array}$ & 10 & 1,350 \\
\hline
\end{tabular}


Table 1.--Lithologic log of test wel1--Continued

Description

Thick-

Depth

ness to base

(feet) (feet)

Limestone, medium-gray, micritic, hard, low porosity, with

1ight- to dark-green glauconite, bryozoan fragments prominent. Trace of pyrite. Pelletal (coarse pellets of white micrite) in 1,355 to 1,360 -foot interval. Dark-gray coarse recrystallized limestone prominent in 1,360 to $1,365-f$ oot interval, increases to 40 percent of rock in 1,370 to $1,375-f$ oot interval.

Limestone, 1ight-gray, pelletal, porous. Estimated 1,405 porosity, 20 percent. 65 percent fine white micrite pellets, bryozoan fragments, and small foraminifera; 35 percent white to light-gray micrite binder. Trace of very fine-grained dark-green glauconite. Large foraminifera very prominent in 1,385 to 1,395 -foot interval. Highly glauconitic in 1,400 to 1,405 -foot interval.

Limestone, medium-gray, pelletal, highly porous. Estimated porosity, 30 percent. 60 percent fine white micrite pellets and fine bryozoan fragments; 40 percent medium gray recrystallized limestone matrix. Fine-grained glauconite prominent.

Limestone, dolomitic, tan, medium to coarse crystalline, low porosity, with white bryozoan fragments prominent, dark-green glauconite common. Small foraminifera and isolated vuggy porosity common in 1,430 to 1,435 -foot interval.

Dolomite, tan with minor black spots, fine crystalline, hard, massive, low porosity.

Dolomite, cream, medium crystalline, sacchroidal, massive, low porosity, with trace of pinpoint vugs. Becomes light-brown with vuggy zones in 1,450 to 1,465 -foot interva1. Coarse crystalline with estimated 25 percent porosity in 1,465 to 1,470 -foot interval.

Limestone, 1ight-gray, pelletal, low porosity; 70 percent fine white micrite pellets, bryozoan fragments and small foraminifera; 30 percent white micrite matrix, partly recrystallized to medium crystalline light-gray calcite. Limestone, medium-gray, pelletal, low porosity; 55 percent fine white micrite pellets and small bryozoan fragments; 45 percent fine crystalline (recrystallized) light-gray to light-brown limestone matrix, with dark-gray spots prominent.

$\begin{array}{ll}15 & 1,420 \\ 15 & 1,435 \\ 5 & 1,440 \\ 35 & 1,475 \\ 5 & 1,480 \\ 5 & 1,485\end{array}$


Table 1.--Lithologic log of test we11--Continued

\author{
Description
}

$\begin{array}{cc}\text { Thick- } & \text { Depth } \\ \text { ness } & \text { to base } \\ \text { (feet) } & \text { (feet) }\end{array}$

Dolomite, light gray with brown tint, medium to coarse crystalline, low porosity, with minor vugs and black spots prominent. Zones of very coarse crystalline porous dolomite prominent in 1,490 to 1,495-foot interval. Limestone as 1,480 to 1,485-foot interval. Limestone, white, micritic, low porosity; about 20 percent recrystallized to fine crystalline clear calcite "floating" in micrite. Fine white micrite pellets prominent. Trace of very fine-grained dark-green glauconite. Decrease in recrystallized calcite to trace, increase in glauconite to prominent in 1,535 to 1,540foot interval.

Limestone, white, pelletal, low porosity; 70 percent fine white micrite pellets, bryozoan fragments, and small foraminifera; 30 percent white micrite matrix. Fine-grained light- to dark-green glauconite common. Trace of pelecypods.

Dolomite, medium-gray, fine crystalline, hard, massive, low porosity, with small black spots common.

Dolomite, 1ight-gray, fine crystalline, hard, massive, low porosity, sacchroidal.

Limestone, white, micritic, soft, low porosity, with trace of pyrite and fine- to medium-grained dark-green glauconite.

Dolomite, light-brown, medium crystalline, sacchroidal, low porosity, with fine-grained glauconite, black algal flakes prominent.

Limestone as 1,585 to 1,600-foot interval. Partly recrystallized to cream very fine crystalline soft dolomite in 1,610 to 1,615 -foot interval.

Dolomite, cream, calcareous, very fine crystalline, hard, massive, low porosity. Trace of black algal (?) flakes. A few white large discoid foraminifera in 1,620 to $1,625-f$ oot interval.

Limestone as 1,585 to 1,600-foot interval. Tan recrystallized limestone prominent in 1,630 to $1,640-$ foot interval.

Limestone, white, micritic, hard, low porosity, with darkgray chert accounting for 40 percent of sample. Chert is replacing limestone. 
Table 1.--Lithologic $\log$ of test well--Continued

Description

Thick-

Denth

ness to base

(feet)

(feet)

Limestone, white, micritic, soft, low porosity, with very

30

1,685

fine-grained light-green glauconite prominent. Hard, with

light-gray chert prominent in 1,665 to 1,670-foot interval.

Increase in glauconite to 15 percent in 1,675 to 1,685 -foot interval.

Limestone, medium-gray with greenish tint, micritic, soft, low porosity; 65 percent white, soft to cream, indurated micritic limestone matrix; 35 percent very fine to finegrained dark-green glauconite.

Limestone, white, micritic, hard, massive, low porosity; very fine-grained light- to dark-green glauconite prominent. Trace of coarse pyrite aggregates, pelecypod casts and molds.

Limestone, light-gray, pelletal, hard, low porosity; 80 percent fine white micrite pellets and rare bryozoan fragments; 20 percent white micrite matrix, partly recrystallized to medium crystalline clear calcite. Very fine-grained light-green glauconite prominent. Echinoid fragments, small foraminifera conmon in 1,720 to $1,725-$ foot interval.

Limestone, light-gray with tan cast, hard, micritic, low porosity, with tan recrystallized calcite, small foraminifera and very fine-grained dark-green glauconite prominent. Trace of white gypsum in 1,745 to 1,755 -foot interval. Trace of oyster fragments, large aggregates of apple-green glauconite in 1,755 to 1,760-foot interval.

Limestone, white, pelletal, hard, micritic, low porosity; 75 percent fine white micrite pellets and small foraminifera; 25 percent light-gray hard micrite matrix. Trace of very fine-grained dark-green glauconite. Soft with no glauconite in 1,770 to 1,780 - and 1,800 to $1,805-$ foot intervals. Porous (estimated porosity, 20 percent) in 1,785 to 1,795 -foot interval.

Limestone, cream, micritic, hard, low porosity, with fineto coarse-grained apple-green glauconite prominent. Trace of dark-gray highly glauconitic limestone lenses with much disseminated pyrite.

Limestone, tan, fine pelletal, hard, low porosity; 80 percent miliolid foraminifera and fine white micrite pellets; 20 percent tan microcrystalline micrite matrix. 
Table 1.--Lithologic $\log$ of test well--Continued

$\begin{array}{ccc} & \text { Thick- } & \text { Depth } \\ \text { Description } & \text { ness } & \text { to base } \\ \text { (feet) } & \text { (feet) }\end{array}$

Limestone, white with tan cast, hard, micritic, massive,

40

1,870

low porosity, very fine crystalline, with silty appearance due to recrystallization of micrite.

Dolomite, tan, medium crystalline, calcareous, hard, low porosity, massive. Very fine crystalline in 1,880 to 1,885 -foot interval.

Limestone as 1,820 to 1,830-foot interval. Micrite matrix white in 1,890 to 1,895 -foot interval. Dark brown algal mats prominent in 1,905 to 1,910 -foot interval.

Limestone, white, soft, pelletal, low porosity, consists of 75 percent very fine micrite pellets and small foraminifera loosely bound by 25 percent soft white micrite matrix.

Limestone, cream, micritic, massive, hard, low porosity. Dark-brown algal mats, medium-brown fine crystalline dolomite stringers prominent in 1,925 to 1,930-foot interval. Black clay (cavity filling) prominent in 1,930 to $1,935-$ and 1,945 to 1,950 -f oot intervals. Miliolid foraminifera abundant in 1,945 to 1,950-foot interval. Limestone, light gray with tan cast, micritic, hard, low porosity; 50 percent white micritic limestone; 50 percent very fine to fine crystalline tan limestone, representing recrystallized micrite. Dark-brown algal flakes abundant. Trace of black woody material in 1,970 to 1,975 -foot interval.

Limestone, 1ight gray, micritic, hard, dense, massive, low porosity. Trace of pinpoint vugs, black fine organic material.

Dolomite, very dark gray with minor dark brown mottling, hard, massive, fine crystalline, low porosity. Becomes medium crystalline in 2,010 to 2,020 -foot interval. 2,010 to 2,015-foot interval is about 30 percent light gray chert. Dolomite is light olive color in 2,020 to 2,025-foot interval.

Dolomite, light-gray, microcrystalline, hard, massive, dense, low porosity. 


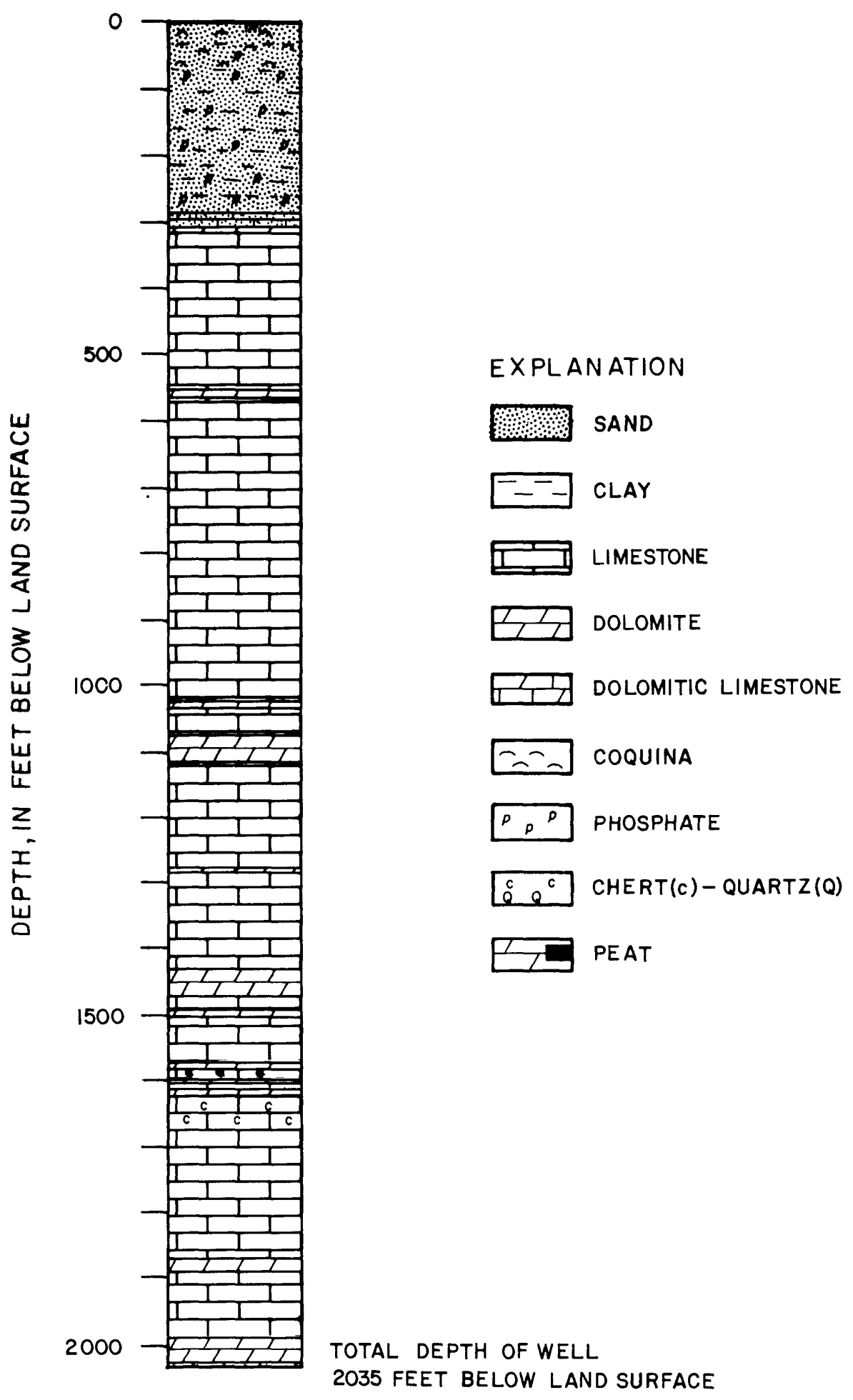

Figure 3.--Lithology at test well site. 
10 MILLIVOLTS

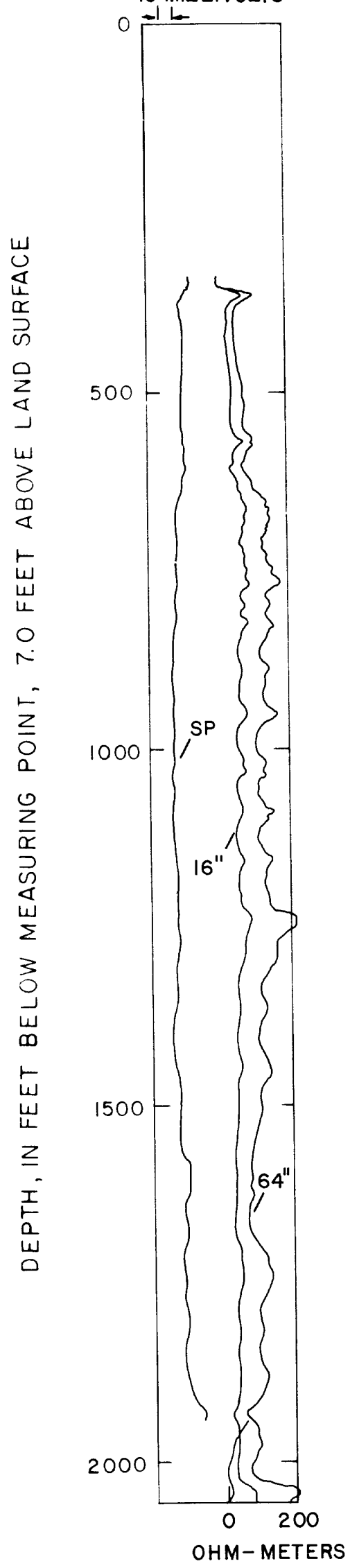

Figure 4.--Electric log; long and short normal resistivity., and spontaneous potential.

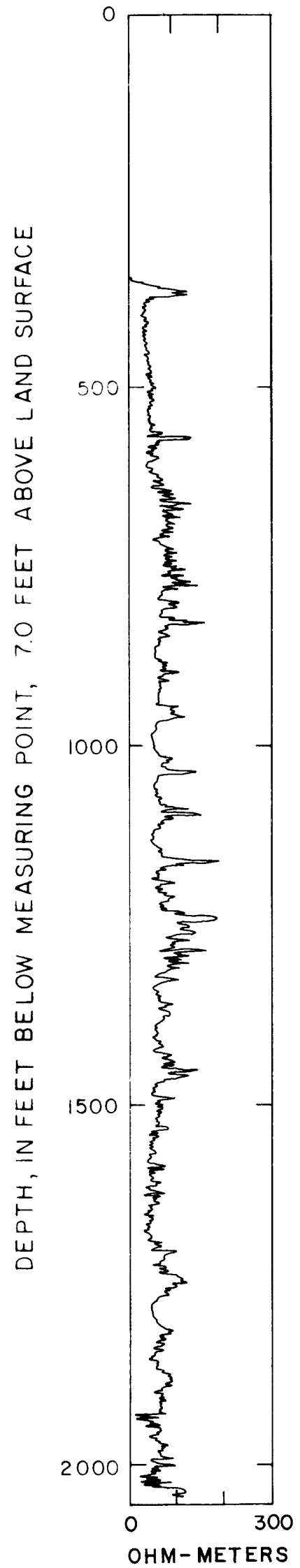

Figure 5.--Electric log (focused resistivity). 

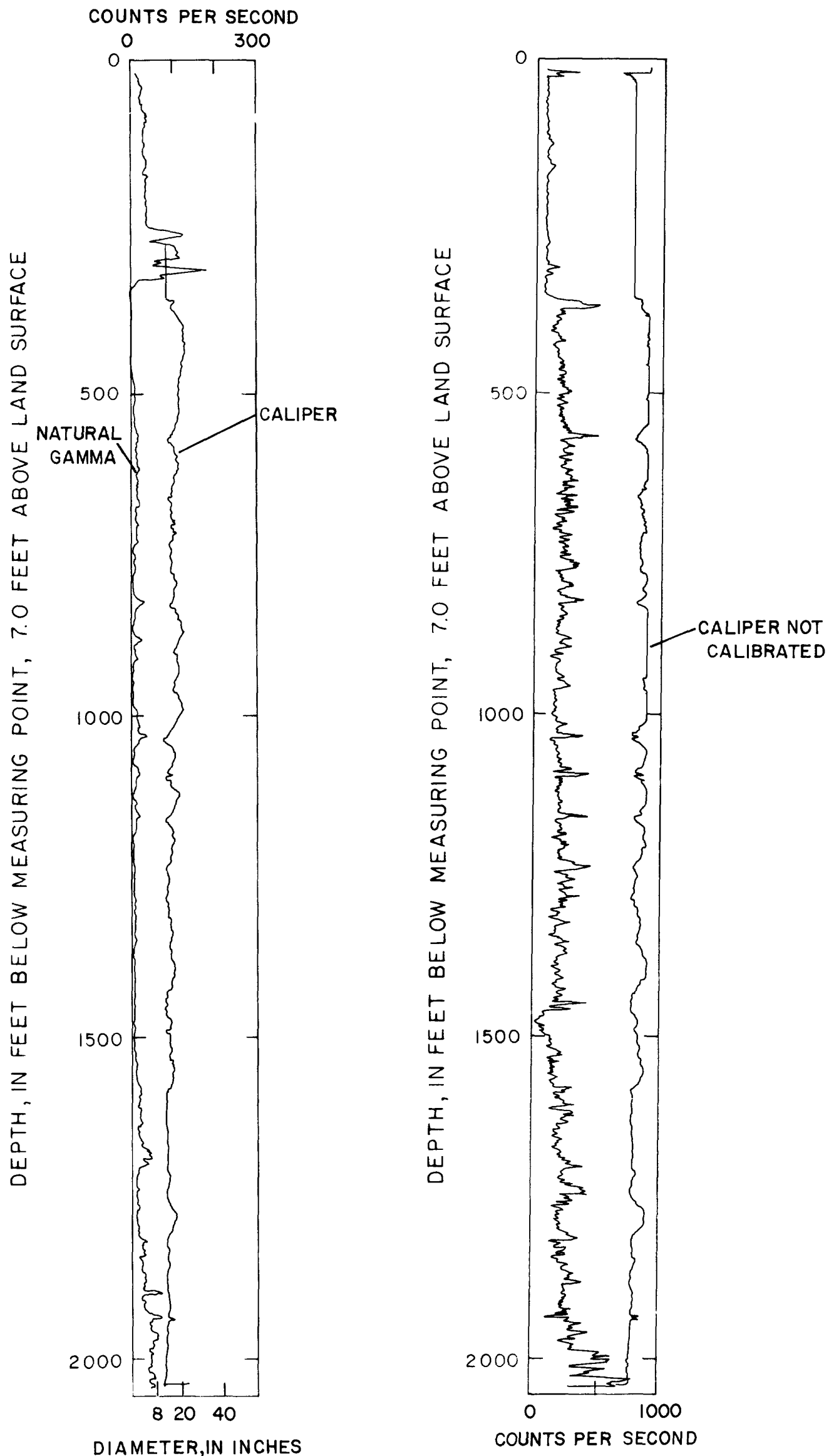

Figure 6.--Caliper and natural gamma 1 log.

Figure 7.--Neutron porosity $\log$. 

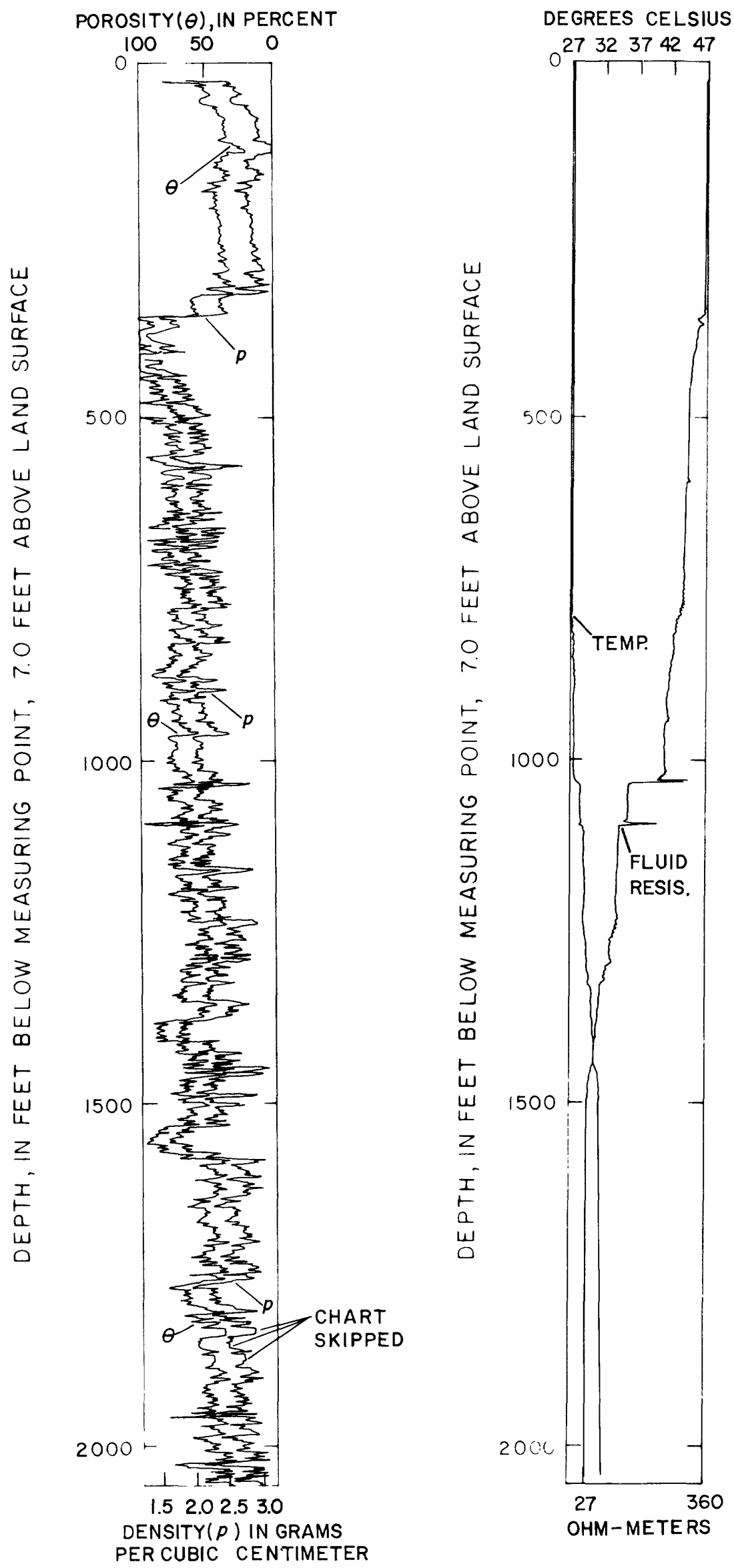

Figure 8.--Gamma-gamma density $\log$.

Figure 9.--Fluid resistivity $\log$. 

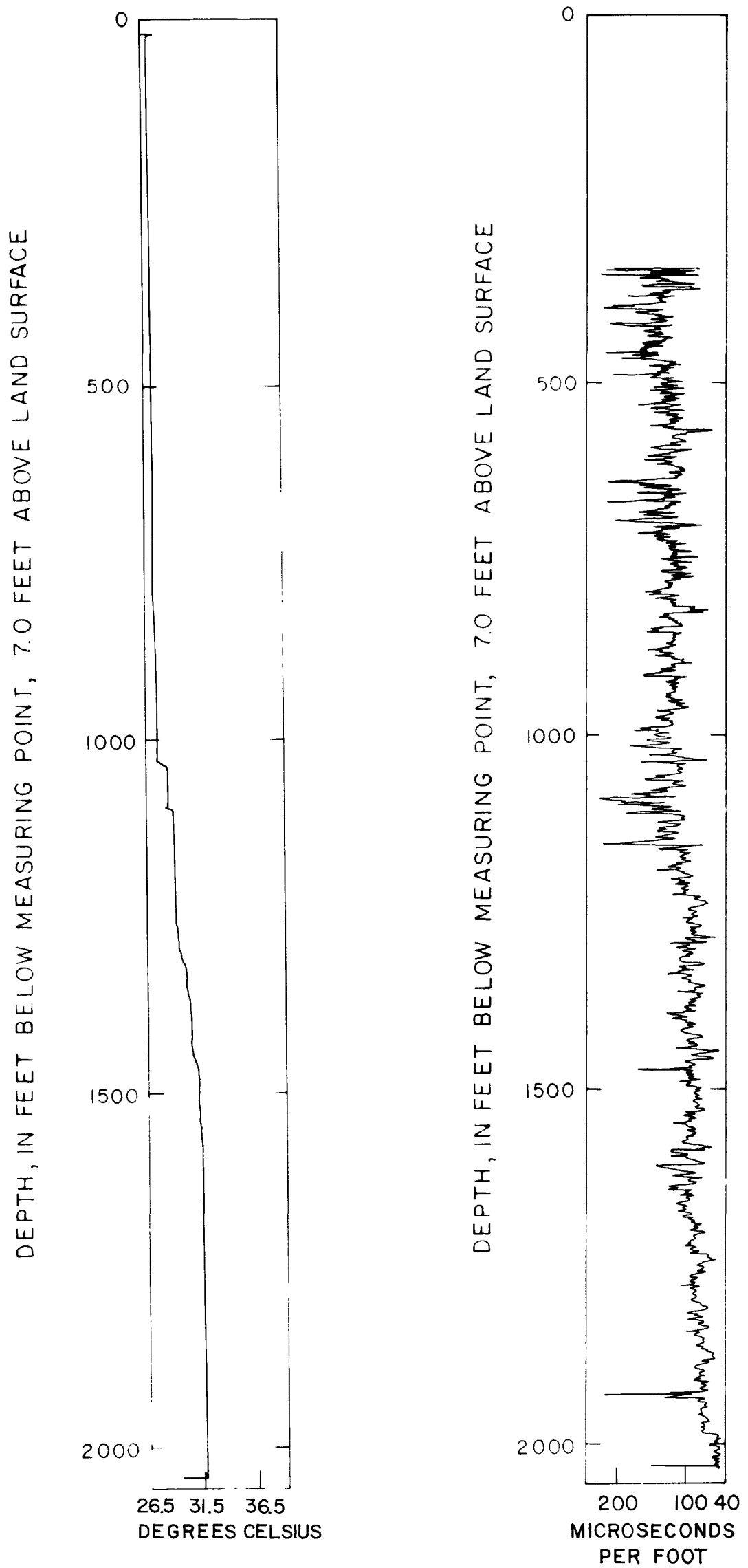

Figure 10.--Tempera :ure log.

Figure 11.--Acoustic velocity $\log$. 


\section{HYDROLOGIC DATA}

\section{Water Levels}

Water levels were measured in the drill stem positioned near or at the bottom of the drill hole and in the annular space between the drilled hole and the drill stem as drilling progressed from 373 to 2,035 feet below land surface (fig. 12). The altitude of land surface at the test site was about 5 to 7 feet above sea level. Water levels measured through the drill stem represent artesian pressures at or near the bottom of the borehole. Annulus water levels represent a composite artesian pressure of the open-hole interval below the surface casing.

Water levels measured through the drill stem as drilling progressed from 373 to 1,980 feet ranged from 24 feet above land surface at a depth of 548 feet to 33.0 feet above land surface at a depth of 1,790 feet. After the lower saline water-bearing zone was penetrated at a depth of 1,983 feet, water level decreased to 4.9 feet below land surface. Water levels measured in the annular space ranged from 23.7 feet above land surface at a depth of 548 feet to 33.1 feet at a depth of 1,790 feet. After the well was completed, water level in the monitored interval (1,980 to 2,035 feet below land surface) was about 5 feet above sea level. Water-level data were not adjusted for density differences between freshwater and mineralized water in the drill stem during drilling and in the completed well.

\section{Artesian Flow}

The artesian flow of the test well with and without the drill stem in the hole was measured periodically during drilling (fig. 13). The flow (drill stem in the hole) increased from about $72 \mathrm{gal} / \mathrm{min}$ at a depth of 338 feet to $2,340 \mathrm{gal} / \mathrm{min}$ at a depth of 1,703 feet. The maximum flow measured (without the drill stem in the hole) was about $3,330 \mathrm{gal} / \mathrm{min}$ at a depth of 2,035 feet.

During drilling, down-hole traverses were made with a flow meter in the open-hole intervals of 335 to 818 feet, 335 to 1,381 feet, and 335 to 2,035 feet (figs. 14-16). Traverses were made with the well naturally flowing at $1,500 \mathrm{gal} / \mathrm{min}, 2,800 \mathrm{gal} / \mathrm{min}$, and $3,500 \mathrm{gal} / \mathrm{min}$, respectively, and with the well shut-in at the 335-to 1,381-foot and 335-to 2,035-foot intervals.

\section{Water Chemistry}

Figures 17, 18, and 19 show the specific conductance, chloride concentrations, and temperature of drill stem and annulus water samples as drilling progressed from 342- to 2,035-foot depths. Specific conductance ranged from 450 to $46,000 \mu \mathrm{mho} / \mathrm{cm}$ at $25^{\circ} \mathrm{C}$ in the drill stem samples and from 525 to $2,060 \mu \mathrm{mho} / \mathrm{cm}$ in the annulus samples. Chloride concentrations of drill stem samples ranged from 12 to $16,210 \mathrm{mg} / \mathrm{L}$. Chloride concentrations of drill stem samples ranged from 12 to $31 \mathrm{mg} / \mathrm{L}$ from a depth of 343 to 1,023 feet and then increased to $270 \mathrm{mg} / \mathrm{L}$ at 1,025 feet. Chloride concentrations ranged from 100 to $270 \mathrm{mg} / \mathrm{L}$ to a depth of 1,083 feet. Below 1,083 feet, chloride concentrations ranged from $12 \mathrm{mg} / \mathrm{L}$ to $38 \mathrm{mg} / \mathrm{L}$ to a depth of 1,983 feet. From a depth of 1,983 feet to 2,035 feet, chloride increased from $38 \mathrm{mg} / \mathrm{L}$ to a maximum of $16,210 \mathrm{mg} / \mathrm{L}$. The water temperature from the drill stem samples ranged from 23 to $27^{\circ} \mathrm{C}$, generally increasing with depth. 


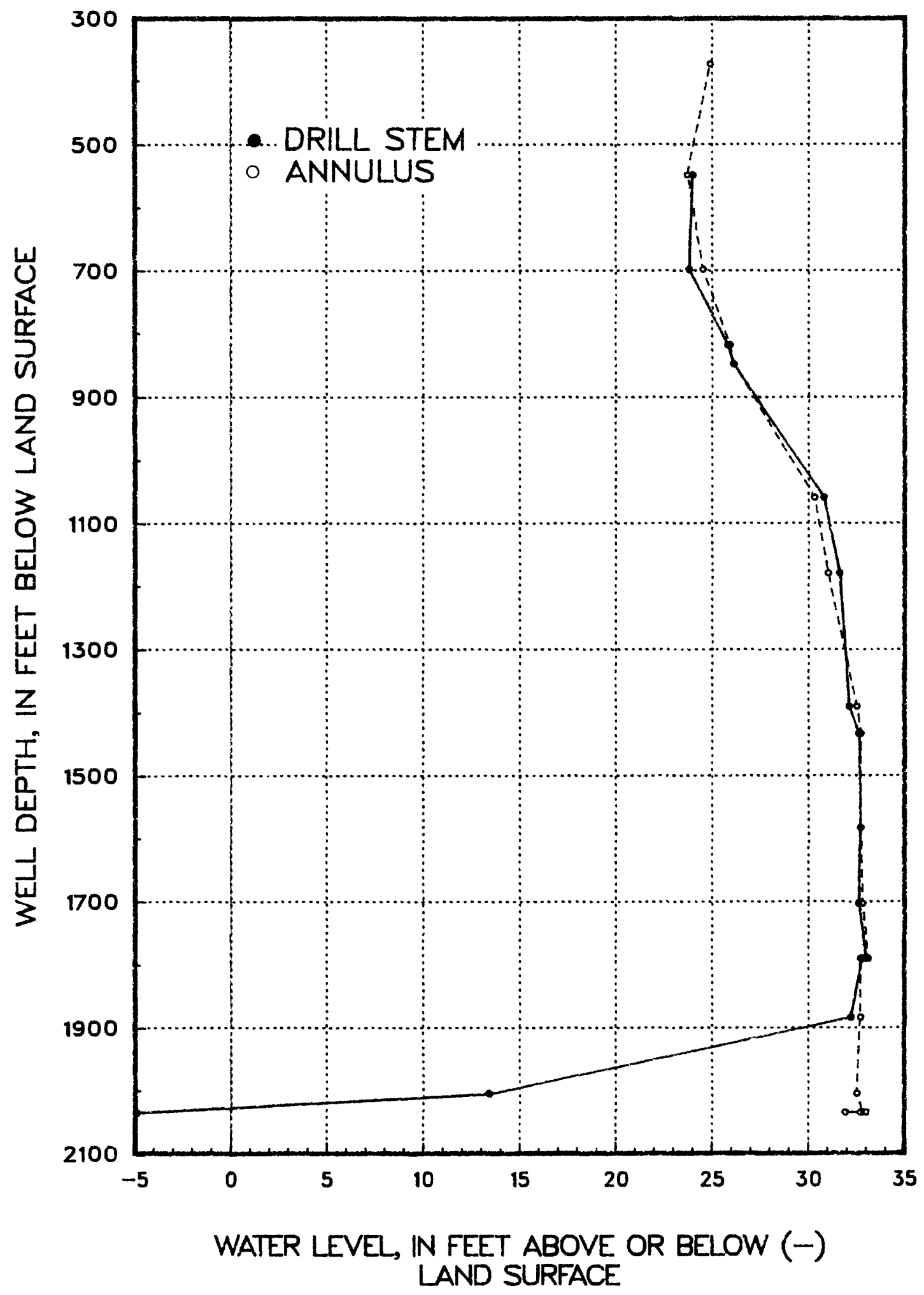

Figure 12.--Water levels in drill stem and in annulus during drilling of test well. 


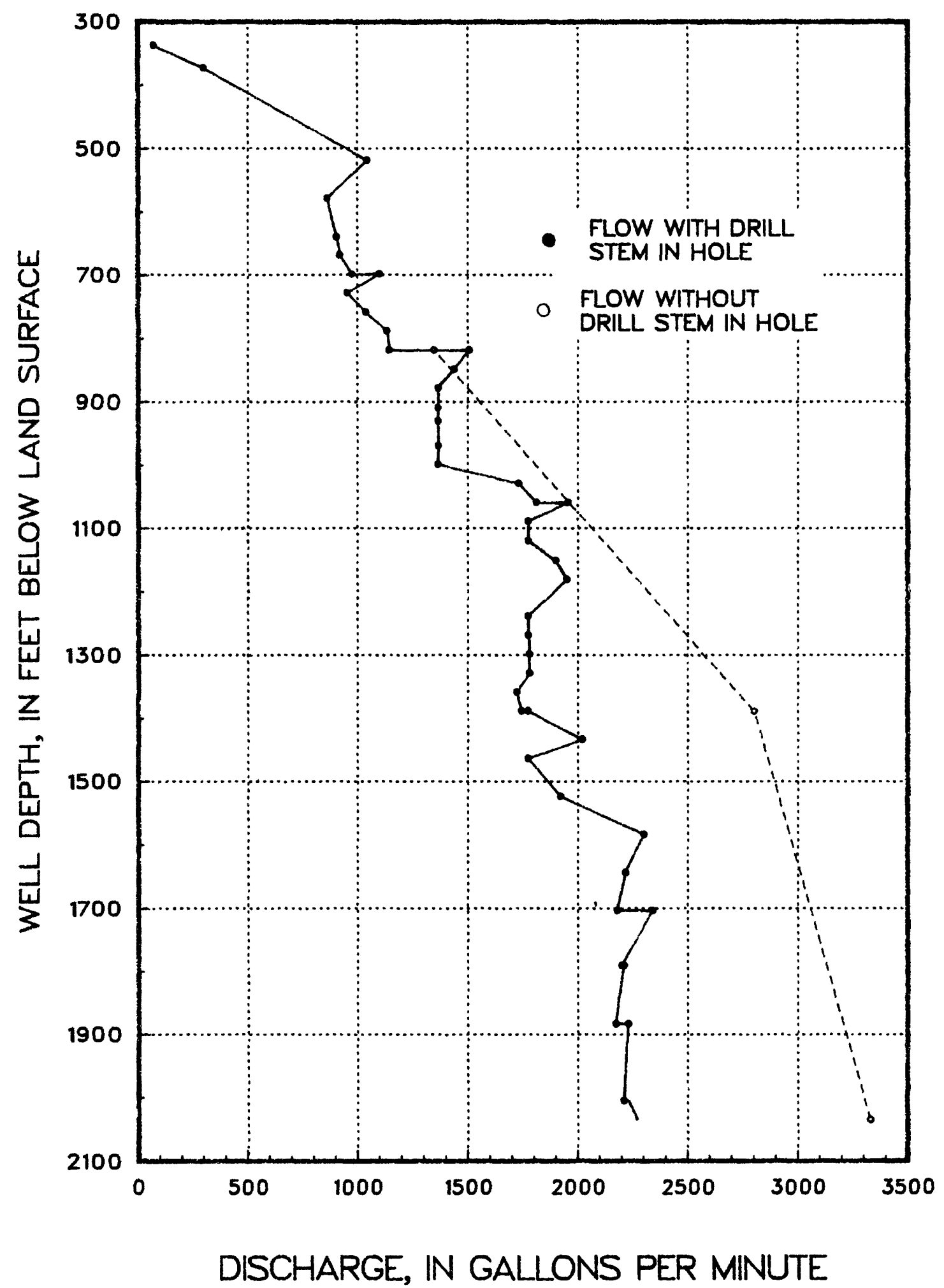

Figure 13.--Artesian flow of test well during drilling. 


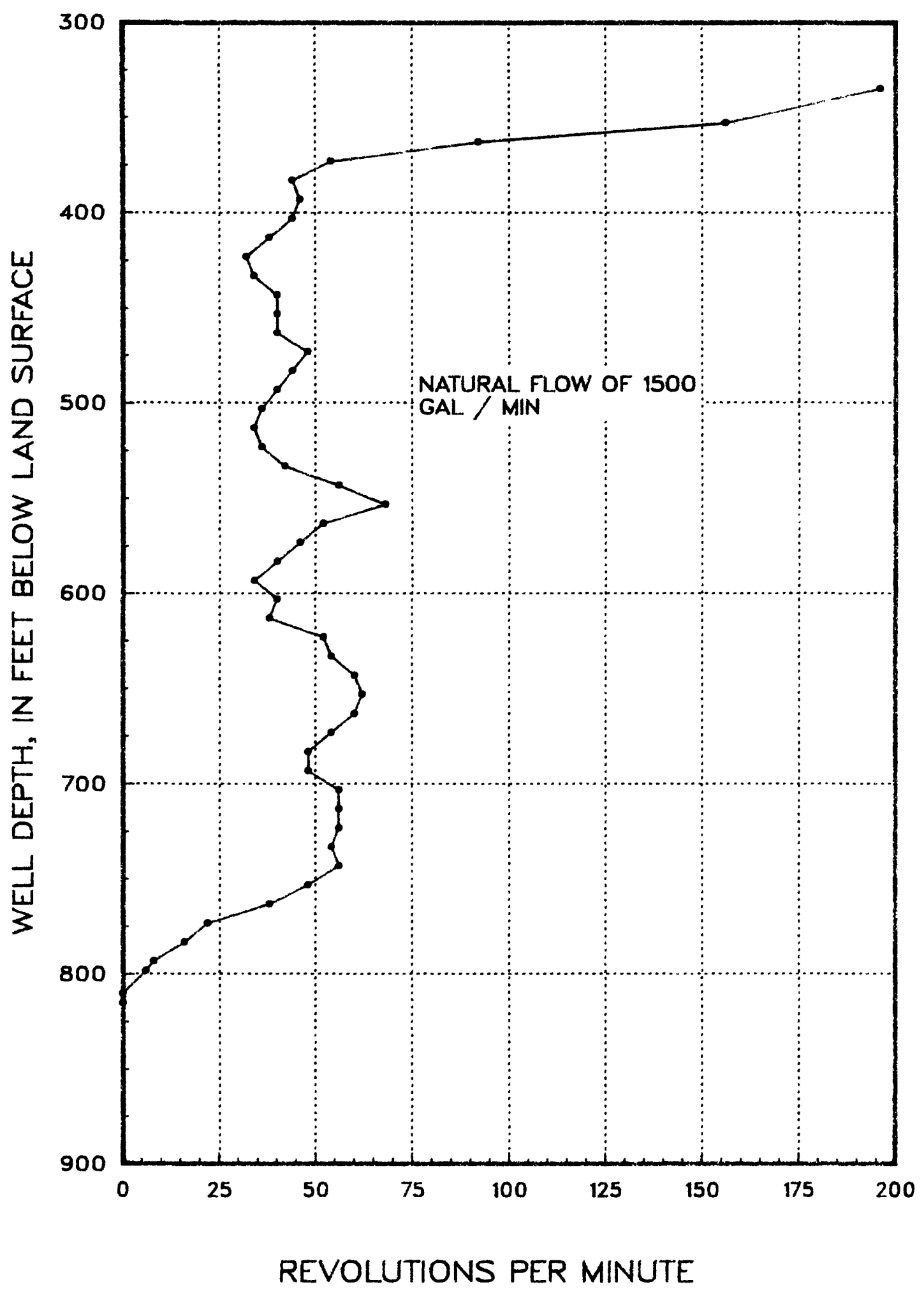

Figure 14.--Flow-meter traverse in test well, open-hole interval 335 to 818 feet below land surface. 


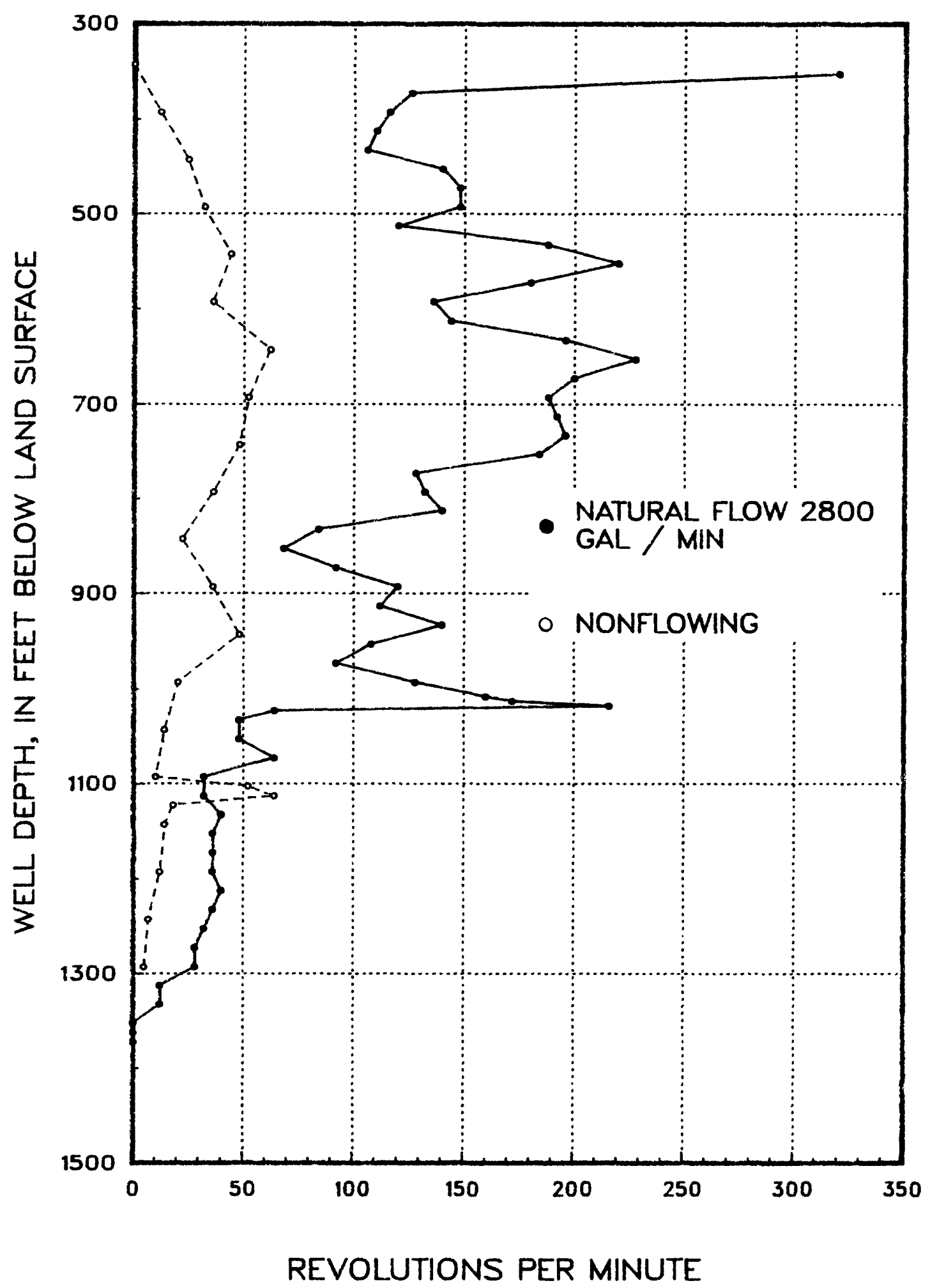

Figure 15.--Flow-meter traverses in test we11, open-hole interval 335 to 1,381 feet below land surface. 


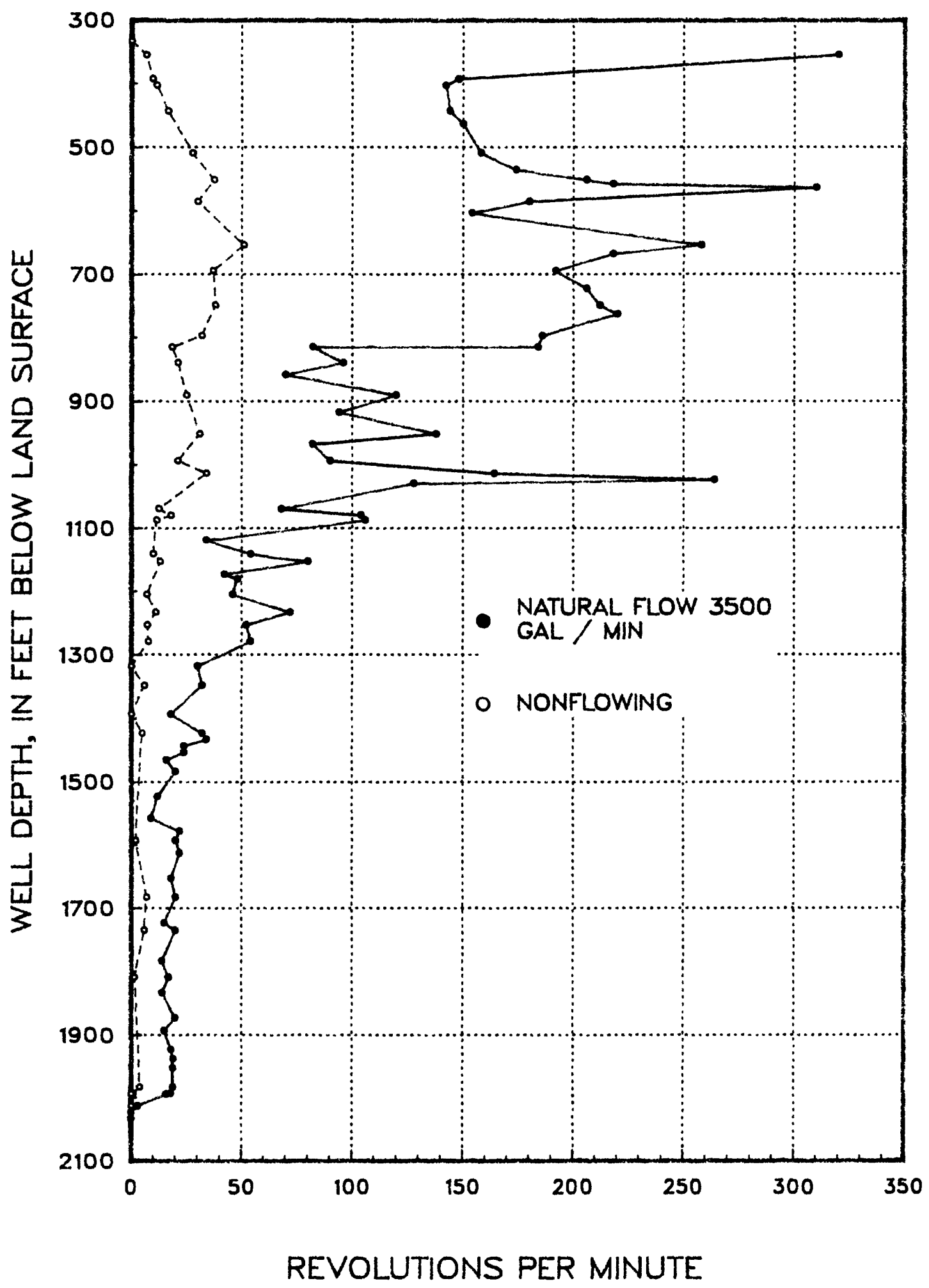

Figure 16.--Flow-meter traverses in test well, open-hole interval 335 to 2,035 feet below land surface. 


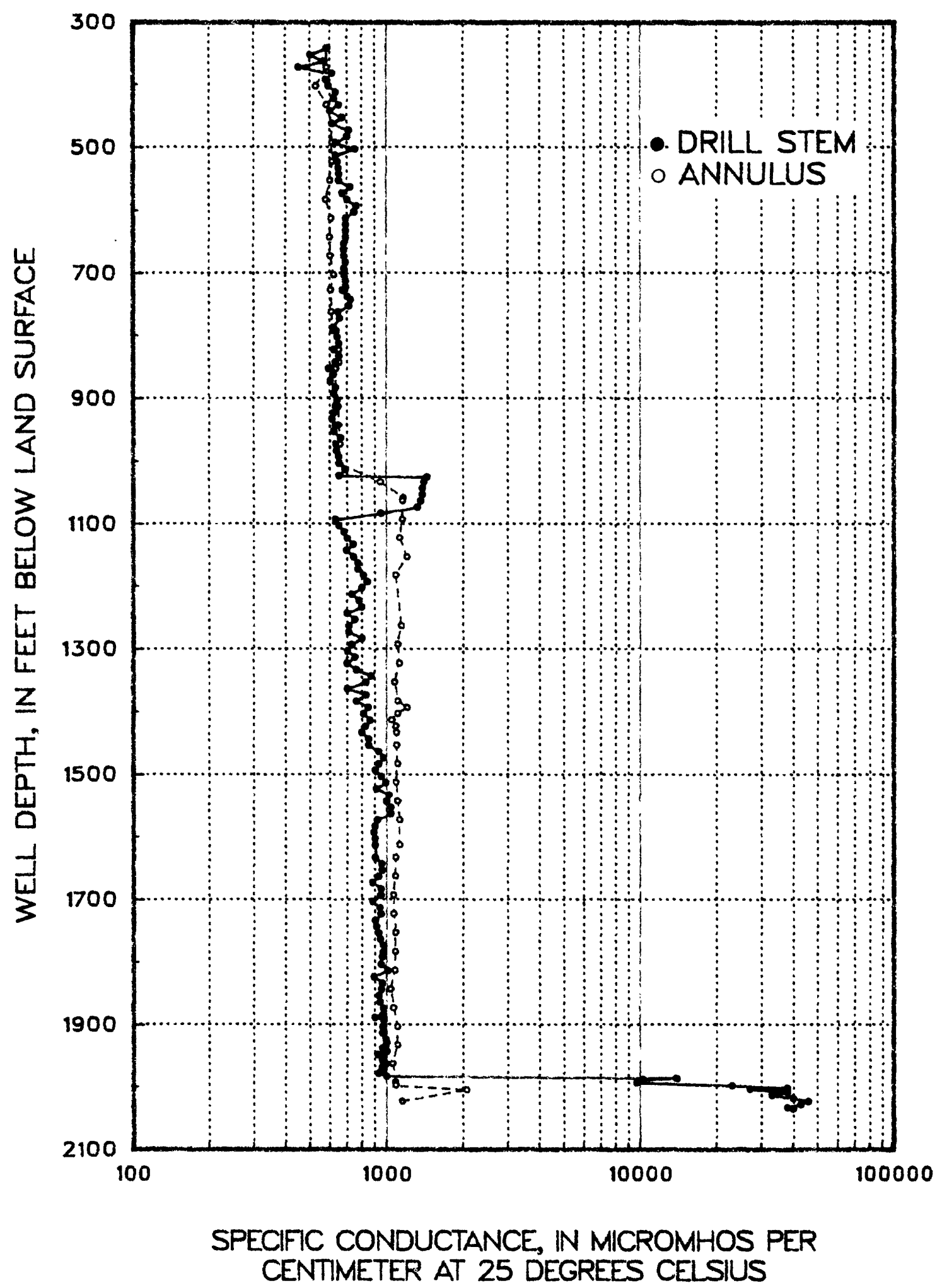

Figure 17.--Specific conductance of water obtained from the drill stem and the annulus as the test well was drilled from 342 to 2,035 feet. 


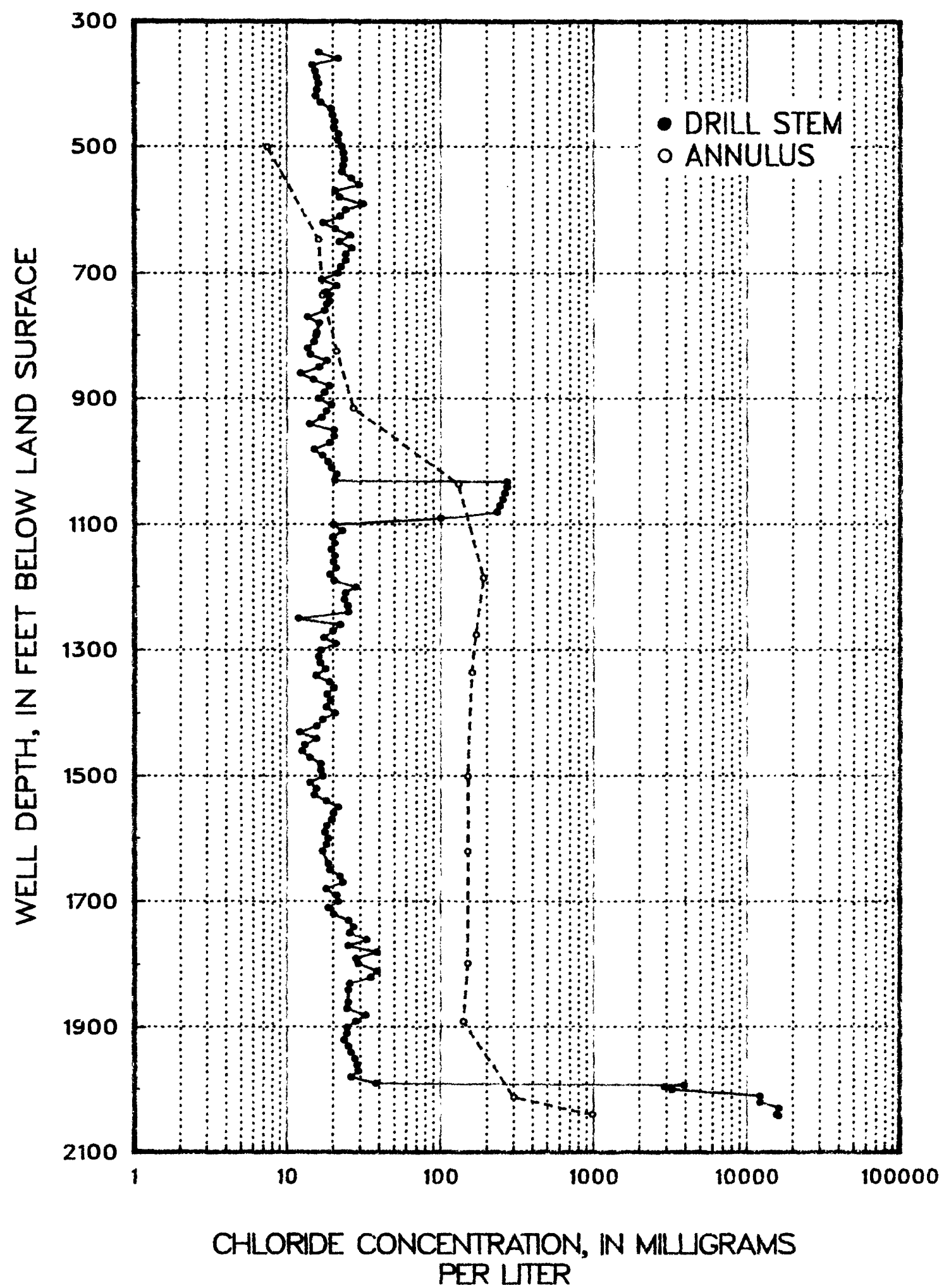

Figure 18.--Chloride concentrations of water obtained from the drill stem and annulus as the test well was drilled from 342 to 2,035 feet. 


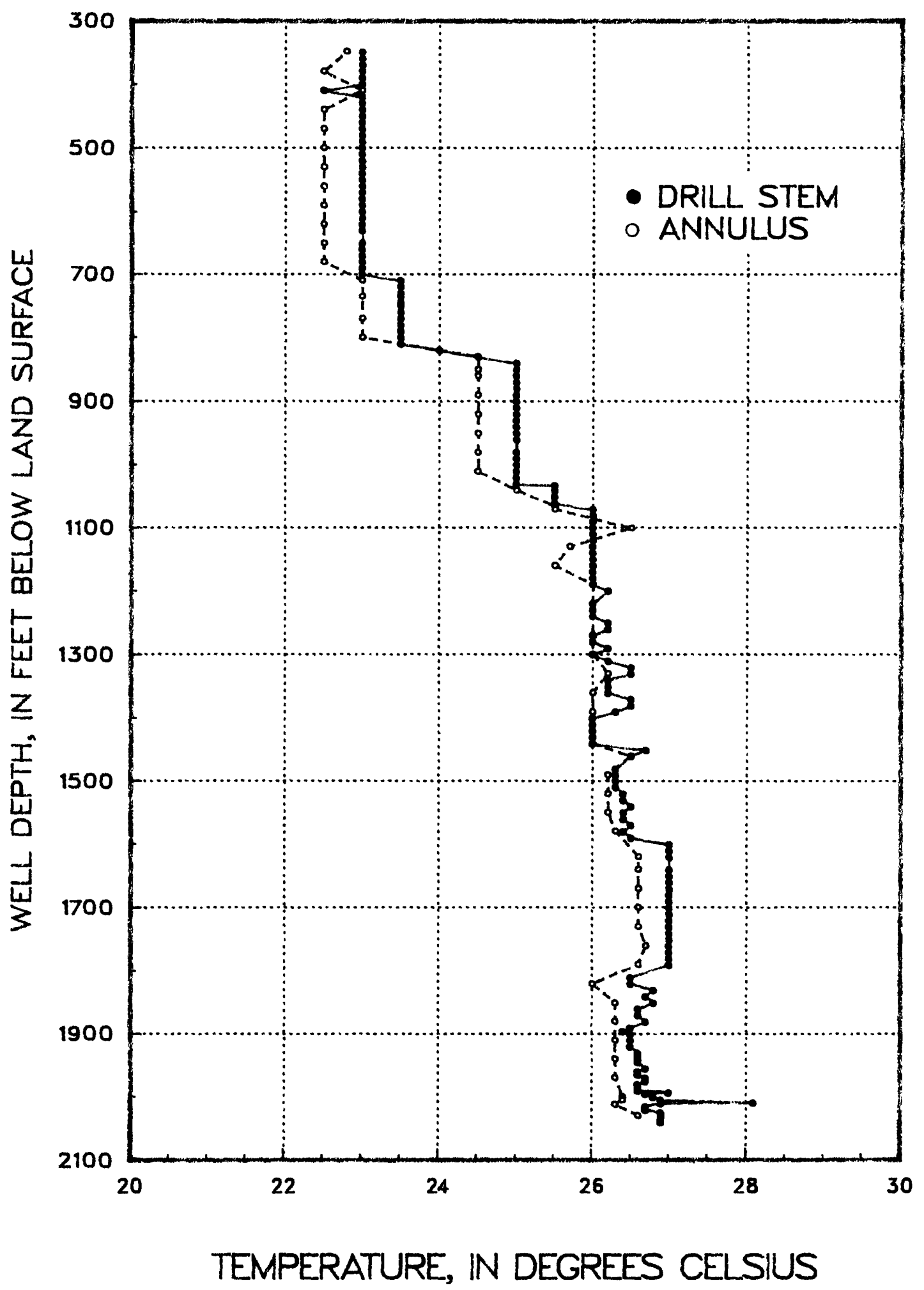

Figure 19.--Temperature of water obtained from the drill stem and annulus as the test well was drilled from 342 to 2,035 feet. 


\section{SELECTED REFERENCES}

Brown, D. P., Johnson, R. A., and Baker, J. S., 1984, Hydrogeologic data from a test well at Kathryn Abbey Hanna Park, City of Jacksonville, Florida: U.S. Geological Survey Open-File Report 84-143, 48 p.

Brown, D. P., Johnson, R. A., and Broxton, R. A., 1985, Hydrogeologic data from a test well in east-central Duval County, Florida: U.S. Geological Survey Open-File Report 84-802, 61 p.

Cooper, H. H., Jr., Kohout, F. A., Henry, H. R., and Glover, R. E., 1964, Sea water in coastal aquifers: U.S. Geological Survey Water-Supply Paper 1613-C, p. 1-84.

Lohman, S. W., and others, 1972, Definitions of selected ground-water terms--revisions and conceptual refinements: U.S. Geological Survey Water-Supply Paper 1988, 21 p.

Miller, J.A., 1986, Hydrogeologic framework of the Floridan aquifer system in Florida and in parts of Georgia, Alabama, and South Carolina: U.S. Geological Survey Professional Paper 1403-B, 89 p. 